Robert Sabo, Katarína Vančíková, Terézia Vaníková, Denisa Šukolovă Slovakia

\title{
Social Representations of Inclusive School from the Point of View of Slovak Education Actors
}

DOI: 10.15804/tner.2018.54.4.20

\begin{abstract}
The aim of the study was to identify social representations of inclusive school from the point of view of Slovak education actors. Q-methodology (Stephenson, 1953) was used for the purpose of mapping. A set of 57 items was compiled, representatively representing associations with the meaning "inclusive school". The items were sorted by 32 participants aged from 25 to 58. Five significant factors were identified, which represented various inclusive school representations linked to: 1) tradition of integration, 2) institutional processes of education quality assurance, 3) priority in declaration of pro-inclusive setting, 4) community co-existence, and 5) needs of a modern society. Preliminary interpretation of the representations from the viewpoint of participants' additional characteristics is described in the discussion.
\end{abstract}

Keywords: social representations, inclusion, education actors

\section{Introduction}

By ratification of international agreements, Slovakia has committed itself to restrict internal and external selection and thus to provide quality education for all children regardless of their accidental characteristics. By becoming a member of the European Agency for the Development of Special Needs Education in 2012, Slovakia made a promise to improve the availability of education to everyone, while pursuing consistent application of principles of inclusion in education in 
its reform steps. Despite formal declarations, there is no general consensus in respect of the essence, meaning or feasibility of inclusive education (hereinafter IE) (Petöcz, 2015).

Although the topic begins to resonate in political discourse, so far there has been no explicitly declared requirement for IE. In addition, even in the case of political consensus, implementation of pro-inclusion measures may encounter public resistance. Its example is the Czech Republic, where introduction of IE into legislation and school practice has raised literally "anti-inclusion hysteria". ' Schooling in the SR and CR traditionally operates on the principle of two parallel streams. One is the vertically built system of the so-called mainstream schools attended by the majority of population within compulsory school attendance, while the minority represented by pupils with special educational needs learns in the system of special schools with a minimum possibility of transfer to the system of mainstream schools. The resistance to inclusive education may be inferred also from the knowledge of the population's social mentality, which is more oriented to exclusion of differences in the broadest sense than their inclusion into the social mainstream.

For the social processes of new ideas adoption or rejection, interpretation of IE by education actors is extremely important. They include teachers and other pedagogical and professional staff at school. It is them who are the key medium through which the public forms its opinion. Therefore, we have been concerned about what the education actors' shared idea of inclusive school is like, and what is common and characteristic of this idea. At the interpretation level, we are looking for the answer to the question what influences their thinking about this concept. Our formulation of the research problem is based on the knowledge that the IE concept has various forms in various countries (Ainscow et al., 2006). As emphasized by Clough and Corbert (2001), the character of concrete inclusion practice is connected with the tradition of that country, as well as with how research has changed the view of that issue.

We rely on the theory of social representations (hereinafter SORs). SOR research helps to reveal people's views concerning various life problems (cf., e.g., Herzlich, 1973; Joffe, 1995, etc.). SOR is understood here as a summary of opin-

1 Cf.: The ideal of inclusion does not really exist, inclusive education does. Response by the Deputy Minister of Education, Stanislav Štech, to an article in Učitelské noviny (Teachers' Gazette) (No. 9/2016). Available on: http://www.msmt.cz/ministerstvo/novinar/ideal-inkluze-skutecne-nefunguje-inkluzivni-vzdelavani-ale 
ions and beliefs formed in social groups, homogenizing the understanding and assessment of the world through consensual construction of reality (Plichtová, 1998). Thinking is strongly influenced by values corresponding to the social and ideological system and history of the concerned group (Abric, 2003). An important role is played also by current social events (Moscovici, 1961) or interpretative assumptions shaping experience already before the person enters into a certain situation (Fay, 1996). In this context, it may be expected that SORs of inclusive school in Slovakia will develop at least against the background of the following events and cultural schemes: (1) Strong tradition of the special education system, where segregation is perceived as an effective tool of help; (2) persisting collectivism as the inheritance of socialism, shaping subjective teaching conceptions and methods; (3) period ethical individualism emphasizing discourse on human rights and equality; (4) tension between the majority population and the Roma ethnic group and strengthening moralizing discourse on socially excluded groups of population; (5) confrontation with the migration crisis and opposition to immigrants and asylum seekers.

\section{Methodology}

To determine SORs, Q-methodology was used, facilitating a systematic study of subjectivity. It includes quantitative analysis of data in combination with a qualitative interpretative framework, thus being one of a few mixed methodological approaches (Stenner, Stainton, 2004; Cross, 2005). Every participant expresses his/ her opinion by sorting a set of statements. Subsequently, using factor analysis based on a correlation of persons, shared systems of ideas and beliefs occurring in the tested sample are identified. The possibility to reveal preferential opinion systems that could not be otherwise expressed by participants is considered a particular strength of Q-methodology (Baker et al., 2010).

\section{Compilation of the Q-set and creation of the quasi-normal distribution matrix}

In creation of the Q-set, statements were gathered through on-line forms (filled in by 158 respondents), where education actors completed any number of incomplete sentences of the wording: "Inclusive school is a school where..." Obtained statements were reduced and formalized by four assessors independently of each other and in several phases, so that they: (1) included only one thought; (2) meanings were not repeated; (3) plain language was used; and (4) statements had 
a sufficient differentiating value. In the end, a set of 57 items was compiled, for which a quasi-normal distribution matrix was created. The scale range (11 points) and its slope were chosen according to recommendations for 40- to 60-item Q-sets (Watts, Stenner, 2012) (cf., Picture 1).

\begin{tabular}{ccccccccccc}
\hline-5 & -4 & -3 & -2 & -1 & 0 & 1 & 2 & 3 & 4 & 5 \\
\hline$?$ & $?$ & $?$ & $?$ & $?$ & $?$ & $?$ & $?$ & $?$ & $?$ & $?$ \\
$?$ & $?$ & $?$ & $?$ & $?$ & $?$ & $?$ & $?$ & $?$ & $?$ & $?$ \\
$(2)$ & $?$ & $?$ & $?$ & $?$ & $?$ & $?$ & $?$ & $?$ & $?$ & $(2)$ \\
& $(3)$ & $?$ & $?$ & $?$ & $?$ & $?$ & $?$ & $?$ & $(3)$ & \\
& & $(4)$ & $?$ & $?$ & $?$ & $?$ & $?$ & $(4)$ & & \\
& & & $?$ & $?$ & $?$ & $?$ & $?$ & & & \\
& & & $(6)$ & $?$ & $?$ & $?$ & $(6)$ & & & \\
& & & $?$ & $?$ & $?$ & & & & \\
& & & $(8)$ & $?$ & $(8)$ & & & & \\
& & & & $?$ & & & & &
\end{tabular}

The upper line presents the reference scale on which statements were differentiated (- 5 - statement describes me the least, 0 - vague statement (neither, nor); 5 - statement describes me the most). Each position on the scale could be placed a given number of statements in the brackets.

Picture 1. Fixed matrix of a quasi-normal distribution

\section{Sampling and the data gathering procedure}

The sample consisted of 32 education actors aged 25 to 58 (average age was 36.9 years). Table 1 presents an overview of the participants and their characteristics. ${ }^{2}$

Table 1. Participants' characteristics

\begin{tabular}{ll}
\hline \multicolumn{1}{c}{ Gender } & \multicolumn{1}{c}{2 (man), 30 (woman) } \\
\hline $\begin{array}{l}\text { Length of school } \\
\text { experience }\end{array}$ & $5(0-5$ years), 5 (5-10 years), 3 (10-15 years), 6 (15-20 years), 4 (20-25 \\
Education & $\begin{array}{l}\text { years), 6 (25-30 years) } \\
\text { education - stage 2), 6 (higher education - stage 3) }\end{array}$ \\
\hline
\end{tabular}

2 In Q-methodology, the sampling logic is not subject to the homogeneity rule. If the aim is to study subjectivity, the sample of participants must include an assumption of differentiation in the view of the subject studied - the more heterogeneous the sample, the better (Lukšík, 2013). The sample size is determined by the statistical analysis used (its inverse character) requiring that the number of participants is two times less than the number of items (Stenner, Stainton, 2004). From this point of view, sampling is a combination of convenience and stratified sampling. 


\begin{tabular}{ll}
\hline \multicolumn{1}{c}{ Gender } & \multicolumn{1}{c}{2 (man), 30 (woman) } \\
\hline Position & $\begin{array}{l}7 \text { (head teacher), 13 (teacher), 1 (teaching assistant), 7 (other profes- } \\
\text { sional employee) }\end{array}$ \\
\hline Profession & $\begin{array}{l}11 \text { (teacher), 1 (higher education teacher), 4 (kindergarten teacher), 2 } \\
\text { (primary education teacher), 5 (school psychologist), 3 (special educa- } \\
\text { tion teacher), 1 (teaching assistant), 2 (head teacher) }\end{array}$ \\
\hline School type & $\begin{array}{l}8 \text { (kindergarten ), 14 (elementary school), } 7 \text { (other - special school, } \\
\text { higher education institution) }\end{array}$ \\
\hline $\begin{array}{l}\text { Experience with the } \\
\text { disabled }\end{array}$ & 1 (in family), 5 (at school), 23 (no considerable everyday experience) \\
\hline
\end{tabular}

Note: Three participants failed to fill in socio-demographic characteristics.

\section{Results}

Data were statistically analysed by the program Q-accessor (@ The Epimetrics Group, LLC, 2010-13). 7 factors (rotated using the orthogonal varimax procedure) were identified, explaining together $47.5 \%$ of the total data variance (result above $35 \%$ can be considered valuable - Watts, Stenner, 2012) and including 18 participants. The criterion for including persons into factors was the loading coefficient value higher than 0.40 and the Fuerntratt criterion taking into account, in addition to the loading coefficient, also the cumulation value (similarity to other participants). Of the remaining 14 participants, 3 participants loaded significantly more than one factor at the same time. 1 participant loaded one of the factors above the set level of significance, however, after application of the Fuerntratt criterion, was not included in the factors. None of the identified factors appeared bipolar. What was described were only factors with their value of eigenvalue higher than 1 . Two factors failed to fulfil the condition.

In the description phase, maps of meanings of the factors were created. They were based on items with their placement in a given factor considerably different from their placement in other factors. Next, the context of the meanings was looked for between pronounced statements in the factor (item placed in extreme positions). This interpretation procedure could be labelled as a "bottom-up" procedure, since it concerned a heuristic search for the context between individual statements and their naming (Lukšík, 2013). Table 2 presents a description of the factors and an overview of the participants' characteristics significantly connected with the factors. 
Table 2. Description of the factors

\section{FACTOR A: INCLUSION AS A NATURAL PRINCIPLE OF CHILDREN'S NEEDS SATISFACTION}

$15.08 \%$ of variance; eigenvalue of 4.83 ; description based on 7 people, average age 44 years; factor likely connected with the following characteristics of the participants: higher education of the 2 nd and 3 rd stage, experience of more than 15 years.

IE is not viewed on as a social request, but as a social need. It is neither a part of marketing nor a means of obtaining material support. It is a school connecting pro-inclusion thinking teachers perceiving work as a mission. They do not call for improved conditions; nevertheless, they create individual educational plans thus responding to children's specific educational needs. The school has well set processes of integration of all SEN pupil groups. It does not open special classes, but integrates in mainstream classes. At the same time, it moves forward also gifted children. ITs are an integral part of the school. The school co-operates with external providers of support services. It concentrates on diagnosing, but does not compare children with a general standard. Its approach influences thinking of people in the region; it works with their attitudes to the disadvantaged and inspires solidarity. It sends a signal that every child should attend the school closest to the child's home and everyone has the right for quality education services.

\section{FACTOR B: INCLUSION AS A MEANS TO IMPROVE THE QUALITY} OF EDUCATION PROCESSES

$11.75 \%$ of variance; eigenvalue of 3.76 ; description based on 5 people, average age 32.6 years; factor likely connected with the following characteristics of the participants: without considerable experience of work with the disabled, higher education of the 2 nd and 3rd stage, lesser experience, one participant lacking characteristics.

Well set up internal processes for quality improvement are of priority. The institution does not yield to the pressure of external control, on the contrary, it is internally motivated to improvement. It is sensitive to hidden problems and perceives them as a source of progress. It is not afraid of feedback. It deals with problems in a mutual dialogue with all parties concerned. Management is based on consistent planning and self-evaluation. Otherness is viewed on as a source of personal enrichment, which motivates to admission of children with various educational needs. The school works with its human resources effectively and sensitively. It employs qualified teachers with higher education and promotes professional development of its employees. It creates a supportive environment for education of active and civilly involved people gaining confidence in their own power to influence social processes. It is not perceived as a goal, but as a means to improve the quality of educational processes. 


\section{FACTOR C: INCLUSION AS A DECLARED VALUE OF PRIORITY}

$5.15 \%$ of variance, eigenvalue of 1.65 ; description based on 2 people, one participant lacking characteristics. The factor was loaded by a female school psychologist with experience of many years, having a close disabled relative in family.

The school officially welcomes IE principles presenting itself externally as the ideal of otherness acceptance. It attempts to be a good practice example and create a friendly environment for children. In accordance with I principles, it integrates SEN children into mainstream classes and does not refuse to integrate even Roma children. It welcomes also teachers with disabilities, because it sees a potential in 5 them for a better understanding of disabled children's needs. It motivates teachers to the individual approach, open communication and mutual dialogue. Teachers have sufficient space for freedom and self-realisation. On the one hand, the school is aware of the key role of the teaching employee who has its support; on the other hand, the teaching employee must rely mainly on him/herself and his/ her colleagues, the teaching staff. Management processes reflect rather a tendency to ad hoc dealing with current needs of the school, pupils, staff and parents. So far, attitudes and value pillars are reflected more intensely than the quality of the processes of education individualization through adaptation of goals and means to children's needs.

\section{FACTOR D: INCLUSION AS A NATURAL PART OF COMMUNITY LIFE}

$8.89 \%$ of variance; eigenvalue of 2.85 ; description based on 2 people, age: 40 and 58 , female, higher education of the 2 nd and 3rd stage; type of school: kindergarten and elementary school; experience of more than 20 years; head teacher and teacher, both with considerable experience with disabled pupils.

It is a local type of school. No parent has to drive his/her child outside the village, town or given locality. The community school reflects the diversity of the local population. As being daily confronted with multiculturality, it naturally accentuates the need to search for a unifying principle. It is aware of the fact that collective functioning requires of each member of the school a certain degree of adaptation to the majority. It is not in its power to satisfy individual needs of each teacher or parent. Nevertheless, it is aware of the variety of children's educational needs, which influences educational processes at school. It does not lose time by comparing children with a vague objective standard. On the contrary, it concentrates it attention on the strengths and limits of each pupil and responds to them. It works with them in groups respecting the level of their development. An important feature of the community life is a rich offer of out-of-school activities strengthening relationships among the teachers, school staff, parents and children. 


\section{FACTOR E: INCLUSION AS ONE OF MANY NEEDS OF A MODERN SOCIETY}

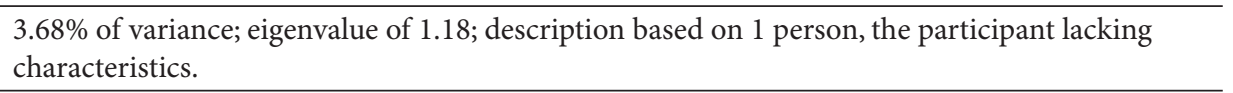

The school responds to the social fact of multiculturality and opens its door to all children. It reflects the social need of I, creating conditions for education of all children in the mainstream. It is aware of the dominant position of the parent in upbringing and respects the parent's protective approach to the child. It knows that it is under parents' scrutiny, therefore it adapts education goals and means to children's educational needs. Thus it satisfies not only children's needs, but also parents' need to be proud of their offsprings. It employs various specialists and forms ITs. It perceives I as a social request to be responded to. It wants to contribute to creation of a more tolerant and cohesive society, emphasizes equal access to cultural resources for disabled citizens. It presents this also outwards. It holds seminars where children openly speak about their disabilities thus getting support from their school mates. It reflects the labour market dynamics and educates children for the current situation. It is aware of the fact that the current generation of children lives in information society requiring development of digital competencies therefore it uses as much ICT as possible.

Legend: IE - inclusive education; I - inclusion; IT - inclusion team; ICT - information-communication technologies

\section{Discussion}

The idea of school with inclusion perceived as a natural principle of children's needs satisfaction (A) is represented by the highest number of participants. They are characterized by a higher age and experience of more than 15 years. They are education actors who participated in the integration effort in the Slovak education system in the nineties of the $20^{\text {th }}$ century. This is likely the reason why they declare the need to respect the needs of all children and the need for equal chances of quality education. The idea of inclusive school is, however, partially deformed by misaligned legislation. Up to the present day, the School Act has integrated a segregation concept of specified groups of children, which could explain the strong emphasis on SEN children integration.

SORs of inclusion as a means of improving the quality of education processes (B) is associated with rather a younger generation of participants with less experience, having achieved higher education of the $2^{\text {nd }}$ and $3 \mathrm{rd}$ stage. The actors endorse participatory forms of school management and emphasize the need for good conditions for teachers' work. Such a school acquires features of a school as a learning organization open to initiatives from outside and to strengthening of 
the synergistic effect (Hopkins, 2001). It is a currently highlighted model, considered very effective because of its increasing capacities for real school improvement in quickly changing conditions (Harris, 2003).

The third characteristic of inclusive school is represented by the idea where inclusion is a declared value of priority $(\mathrm{C})$. The obtained description is based on two people, with one participant having failed to fill in characteristics. Nevertheless, we know that the factor is loaded by a school psychologist with experience of many years, having a disabled close relative in family. We are of the opinion that it is this experience of the actor that may explain the emphasis on declaration of IE values and principles towards the public. The description materializes the idea that school should clearly communicate the message of supportive, accepting and open school admitting children and teachers with disabilities. The description may be a response to the climate in the Slovak society, which is rather contrary to the idea of inclusion. Negative experience with inclusion of the disabled family member into ordinary life is probably so intense that it creates the idea of school publicly endorsing the principles of inclusion, on which it also builds its marketing.

Next, there is a description perceiving inclusion as a natural part of community life (D). This factor is represented by two actors with experience of many years and considerable experience with disabled pupils. The description shows clearly that the inclusive school is perceived as a place that can be attended by all children living in the locality regardless of their characteristics. It is an institution that is not only a place of learning, but also a place of associating. Inclusion is a natural response to the local diversity. We assume that the description is underpinned by the head teacher and teacher's real experience with diversity, thus also the knowledge of its risks. What is noticeable is the inclination to the conception of liberal multiculturality, according to which a multicultural society must show a high degree of solidarity in its members. However, the more diverse it is, the more acute is the need for cohesion and interaction (Parekh, 2000). However, unification of the community requires also a certain rate of conformity and impersonalisation. Thus, inclusion in this school is not an ideal, but an appeal to adjust conditions to individuals' needs, with an emphasis on collective goals of the institution.

In the case of the last SORs, we failed to find out additional characteristics of the participant understanding inclusion as one of many needs of modern society (E). Here, school is perceived as an institution that should follow current trends whether in the area of modern technologies or modern teaching methods and approaches. It is noticeable in the description that the teacher - pupil or teacher - parent relationship is viewed as provision of services with all processes aimed at customer satisfaction. According to this characteristic, school is also an institu- 
tion that should respond not only to trends, but also social problems. That is why inclusion may be understood as a natural response to growing social exclusion and increased tension among groups, and also as a tool for improvement of school leavers and graduates' position in the labour market.

The benefit of the study can be seen especially in the SOR descriptions, which we consider, due to the created set of statements and heterogeneous sample of education actors involved in sorting, to be a sufficiently representative specification of ideas about inclusive school. ${ }^{3}$ In contrast, due to the numbers of the actors examined and their descriptive characteristics, we perceive interpretation of the factors rather as an impetus for further research. It is assumed that inclusive school SORs are influenced also by the respondents' gender (Alghazo Emad, Naggar Gaad, 2004). We recommend taking also the school type (mainstream/special, country/town) into consideration as well as the stage of education system the respondent works at (Schmidt, Vrhovnik, 2015).We have noticed a trend of different thinking in the teaching staff (teacher, teaching assistant) and the staff of specialists (special education teacher, school psychologist, etc), but also differences that may be attributed to the respondent's position at work, where experience with management is likely to play a role (Bailey, Plessis, 1997). It appears that one's own intense experience with a child/person with some type of health disadvantage may be of influence (Parasuram, 2006). In the conditions where the concept of inclusive school is more established, we propose to follow up how inclusive school SORs influence actors' preparedness for co-operation and its quality (Šuc, Bukovec, Žveglič, Karpljuk, 2016).

Acknowledgements

This paper is a result of research within the VEGA project No. 1/0765/16, titled Quality of Selected Components of School Culture as a Condition for Creating an Inclusive School Environment.

\section{References}

Abric, J.C. (2003). Létude experimentale des représentations sociales. In: Les représentations sociales 7., Presses Universitaire de France, pp.203-223.

Ainscow, M. (2006). Improving schools, developing inclusion. London: Routledge.

Alghazo, Emad M., Naggar Gaad, Eman E. (2004). General Education Teachers in the United Arab Emirates and Their Acceptance of the Inclusion of Students with Disabilities. British Journal of Special Education, 31(2), 94-99.

3 In Q-methodology, representativeness is always limited by the number of participants. Therefore, of course, we admit the existence of other inclusive school SORs. 
Bailey, J., Plessis, D. (1997). Understanding principals' attitudes towards inclusive schooling. Journal of Educational Administration, 35(5), 428-438.

Baker, R., Exel, J., Mason, H., Stricklin, M. (2010). Connecting Q \& Surveys: Three Methods to Explore Factor Membership in Large Samples. Operant Subjectivity. 34(1), 1-31.

Clough, P., Lindsay, G. (1991). Integration and the support service. Slough: NFER.

Cross, R.M. (2005). Exploring attitudes: the case for Q methodology. Health Education Research. 20 (2), 206-213.

Fay, B. (1996). Contemporary Philosophy of Social Science: A Multicultural Approach, Oxford, UK, and Cambridge, MA: Blackwell Publishers.

Harris, A. (2003). School improvement. What's in it for schools? London and New York: Routledge Falmer.

Herzlich, C. (1973). Health and Illness. A Social Psychological Analysis. London and New York: Academic Press.

Hopkins, D. (2001). School Improvement for Real. London and New York: Routledge Falmer. Joffe, H. (1995). Social Representations of AIDS: towards Encompassing Issues of Power. Papers on Social Representations, 3, 29-40

Lukšík, I. (2013). Q-metodológia: faktorové zobrazenie ludskej subjektivity. (Q-Methodology: Factor Depiction of Human Subjectivity). Trnava: PF TU v Trnave.

Moskovici, S. (1961). La Psychoanalyse, son image et son public. Paris: PUF.

Parasuram, K. (2006). Variables that affect teachers' attitudes towards disability and inclusive education in Mumbai, India. Disability and Society, 21, 231-42.

Parekh, B. (2000). Rethinking Multiculturalism. Cultural Diversity and Political Theory. New York: Palgrave Press.

Petöcz, K. (2015). Inkluzívne vzdelávanie. In Právo na vzdelanie a jeho klúčové aspekty. (Inclusive Education. In: The Right for Education and its Key Aspects). Bratislava: ŠPU, 65-124.

Plichtová, J. (1998). Sociálne reprezentácie: Teória, výskum, výzva. (Social Representations: Theory, Research, Challenge). Československá psychologie, 42(6), 503-520.

Schmidt, M., Vrhovnik, K. (2015). Attitudes of Teachers towards the Inclusion of Children with Special Needs in Primary and Secondary Schools. Hrvatska revija za rehabilitacijska istraživanja, 51(2), 16-30.

Stenner, P., Stainton, R. (2004). Q Methodology and Qualiquantology: The Example of Discriminating between Emotions. In Todd, Z., Nerlich, B., McKeown, S., Clarke, D.D. Mixing Methods in Psychology. Hove, New York: Psychology Press, Taylor \& Francis Group, 101-120.

Stephenson, W. (1953). The Study of Behavior: Q-Technique and Its Methodology. Chicago: The University of Chicago Press.

Šuc, L., Bukovec, B., Žveglič, M., Karpljuk, D. (2016). Primary School Teachers' Attitudes towards Inclusive Education in Slovenia: A Qualitative Exploration. Journal of Universal Excellence, 5(1), 30-46.

Watts, S., Stenner, P. (2012). Doing Q Methodological Research: Theory, Method and Interpretation. London: SAGE Publications Asia-Pacific. 